\title{
A large unintegrated retrovirus DNA species present in a dermal tumor of walleye Stizostedion vitreum
}

\author{
Daniel Martineau ${ }^{1}$, Randal Renshaw ${ }^{2}$, James R. Williams ${ }^{2}$, James W. Casey ${ }^{2}$, \\ Paul R. Bowser ${ }^{1, *}$ \\ ${ }^{1}$ Department of Avian and Aquatic Animal Medicine, ${ }^{2}$ Department of Microbiology, Immunology and Parasitology, \\ New York State College of Veterinary Medicine, Cornell University, Ithaca, New York 14853, USA
}

\begin{abstract}
Throughout North America, up to $27 \%$ of adult walleye (Pisces: Stizostedion vitreum) are seasonally affected by a dermal tumor termed walleye dermal sarcoma (WDS) which is associated with C-type retrovirus-like particles. A homogenate from 20 pooled tumors was fractionated by sucrose density gradient centrifugation and retrovirus particles were identified by electron microscopy in fractions with high reverse transcriptase (RT) activity. RNA was isolated from a sucrose density gradient fraction which contained a major portion of the RT activity and which had a density of $1.18 \mathrm{~g} \mathrm{ml}^{-1}$ Denaturing gel electrophoresis showed the presence of a minor $12 \mathrm{~kb}$ RNA species, presumed to represent the undegraded genomic RNA of walleye dermal sarcoma virus (WDSV). Digoxigeninlabeled cDNA synthesized from this viral RNA preparation specifically hybridized with a $13 \mathrm{~kb}$ linear unintegrated viral DNA species present only in DNA from walleye tumors. These findings strongly suggest that WDS is the result of an infection caused by a unique exogenous retrovirus of which the unusually large genome is predominantly unintegrated in tumor cells.
\end{abstract}

\section{INTRODUCTION}

Retroviruses have long been suspected to be the causative agents of some fish neoplasms (Walker 1969 Yamamoto et al. 1976, Duncan 1978, Yamamoto et al. 1983, 1985, Masahito et al. 1988). The most convincing evidence has been provided by studies of the northern pike Esox lucius lymphosarcoma, probably the most frequent malignant neoplasm found in wild vertebrates (Sonstegard 1976). Retrovirus-like particles have been observed in homogenates from this tumor (Papas et al. 1976) and experimental transmission by inoculation of cell-free tumor filtrate has been successful (Mulcahy \& O'Leary 1970, Brown et al. 1976). In addition, reverse transcriptase (RT) activity has been detected in sucrose gradient fractions of tumor homogenates with a density consistent with that of retroviruses (Papas et al. 1976). The narrow range of temperature in which experimentally-induced tumors arose and the seasonal prevalence of the tumor support the important role of water

\footnotetext{
- Addressee for reprint requests
}

temperature in the induction of this neoplasm (Brown et al. 1976).

Walleye dermal sarcoma (WDS), a tumor originating in the dermis from the superficial surface of scales (Martineau et al. 1990b), seasonally affects up to $27 \%$ of adult walleye Stizostedion vitreum from Oneida lake, New York, USA (Bowser et al. 1988), and from various parts of North America (Yamamoto et al. 1976, Yamamoto et al. 1985). This neoplasm shares many features with the northern pike lymphosarcoma. First, type-C particles have been observed in experimentally transmitted and spontaneous tumors (Walker 1969, Papas et al. 1976, Yamamoto et al. 1976, Yamamoto et al. 1985). Secondly, the transmissibility of WDS has been demonstrated by inoculation of cell-free tumor homogenate into walleye fingerlings (Martineau et al. 1990a). Thirdly, water temperature has been shown to have a major influence on tumor development (Brown et al. 1976, Bowser et al. 1988, Bowser et al. 1990). Finally, in contrast with their often anaplastic appearance, both the northern pike lymphosarcoma and WDS seem to regress seasonally (Sonstegard 1976, Bowser et al. 1988). However, unlike the northern pike lym- 
phosarcoma, WDS neither invades locally nor metastasizes (Walker 1969, Yamamoto et al. 1976, Yamamoto et al. 1985, Martineau et al. 1990b).

Efforts to further characterize these retroviral agents have been hindered by the lack of an in vitro system to support viral propagation. In order to overcome this limitation, we have used labeled cDNA synthesized from viral RNA isolated from partially purified WDS virions. This allowed us to detect the presence of a homologous viral DNA species present only in walleye dermal sarcoma tissue.

\section{MATERIAL AND METHODS}

Tumor samples. A total of $14 \mathrm{~g}$ of tumor tissue from 20 adult walleyes and $10 \mathrm{~g}$ of normal dermal tissue from 3 different normal walleyes as negative control tissues were collected in April 1989. All tissues were stored at $-70^{\circ} \mathrm{C}$. Additionally, samples of the collected tumors were fixed in $10 \%$ buffered formalin for histologic confirmation of the diagnosis.

Purification of viral particles by sucrose density gradient centrifugation. Tissues were homogenized in $40 \mathrm{ml}$ of TNES (10 mM Tris- $\mathrm{HCl}_{1} \mathrm{pH} 7.5,1 \mathrm{mM}$ EDTA, $100 \mathrm{mM} \mathrm{NaCl}, 5 \%$ sucrose), then centrifuged for $30 \mathrm{~min}$ at $10000 \times \mathrm{g}$. The resulting supernatant fluids were centrifuged for $2 \mathrm{~h}$ at $100000 \times g(\mathrm{~L} 8-80 \mathrm{M}, \mathrm{SW} 28$ rotor, Beckman Instruments, Inc., USA). The pellets were suspended in $0.5 \mathrm{ml}$ of TNES with $6 \mathrm{mM}$ dithiothreitol (DTT) and layered on a $36 \mathrm{ml}, 15 \%$ to $60 \%$ $(\mathrm{w} / \mathrm{v})$ sucrose density gradient. Following centrifugation for $16 \mathrm{~h}$ at $100000 \times g$ (Beckman, SW28 rotor), fractions $(2 \mathrm{ml})$ were collected from the bottom of the tubes. The density and absorbance of individual fractions at $280 \mathrm{~nm}$ were determined by measurement of refractive index and by spectrophotometry, respec- tively. RT activity was measured as described below. Fractions with the highest RT activity were pooled and recentrifuged under identical conditions. All fractions were subsequently stored at $-70^{\circ} \mathrm{C}$.

Electron microscopy. Three fractions with high RT activity obtained from a different identical purification procedure were diluted with TNE to ca $10 \%$ sucrose (final concentration) and pelleted at $100000 \times g$ for 12 min (TL 100, TLA 100.3 rotor, Beckman). The resulting pellet was resuspended in $0.5 \mathrm{ml}$ TNE. From this suspension, several $10 \mu \mathrm{l}$ aliquots were sequentially placed on Formvar-coated grids and were allowed to dry between each application. One drop of a mixture of phosphotungstic acid and bacitracin $\left(100 \mu \mathrm{g} \mathrm{ml} \mathrm{m}^{-1}\right)$ as wetting agent $(5: 1)$ was placed on the grid and the excess was blotted off with filter paper. The sample was examined with an electron microscope (Philips EM-301) at $80 \mathrm{kV}$.

Reverse transcriptase assay. An aliquot $(10 \mu)$ of each sucrose gradient fraction was assayed in a final volume of $50 \mu \mathrm{l}$ containing $50 \mathrm{mM}$ Tris- $\mathrm{HCl}, \mathrm{pH} 7.8$, $60 \mathrm{mM} \mathrm{KCl}, 0.6 \mathrm{mM} \mathrm{MnCl}_{2}, 2 \mathrm{mM} \mathrm{DTT}, 20 \mu \mathrm{g} \mathrm{ml} \mathrm{ml}^{-1}$ polyriboadenylic acid, 0.34 unit $\mathrm{ml}^{-1}$ oligo-deoxythy-

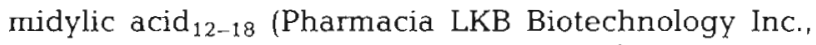
USA), $0.2 \%$ Triton $\mathrm{X}-100$, and $2 \mu \mathrm{M}\left[{ }^{3} \mathrm{H}\right]$ thymidine triphosphate $\left.\left({ }^{3} \mathrm{H}\right] \mathrm{dTTP}\right)$ (sp. act. $46 \mathrm{Ci} \mathrm{mM}^{-1}$ ) (Amersham/Searle, USA). The mixture was incubated for $2 \mathrm{~h}$ at $25^{\circ} \mathrm{C}$ and spotted directly onto strips of ion exchange filter paper (DE-81, Whatman Int. Ltd, UK). The strips were then washed 5 times with gentle rocking at room temperature for $5 \mathrm{~min}$ in $2 \%$ sodium phosphate followed by $1 \mathrm{~min}$ in distilled water and $1 \mathrm{~min}$ in $95 \%$ ethanol. The paper strips were dried and the amount of incorporated $\left[{ }^{3} \mathrm{H}\right] \mathrm{dTTP}$ was measured with a scintillation counter (LS 1801, Beckman).

RNA isolation. Total RNA isolated from $1 \mathrm{ml}$ of one of the 2 sucrose gradient fractions $(4 \mathrm{ml})$ with the highest

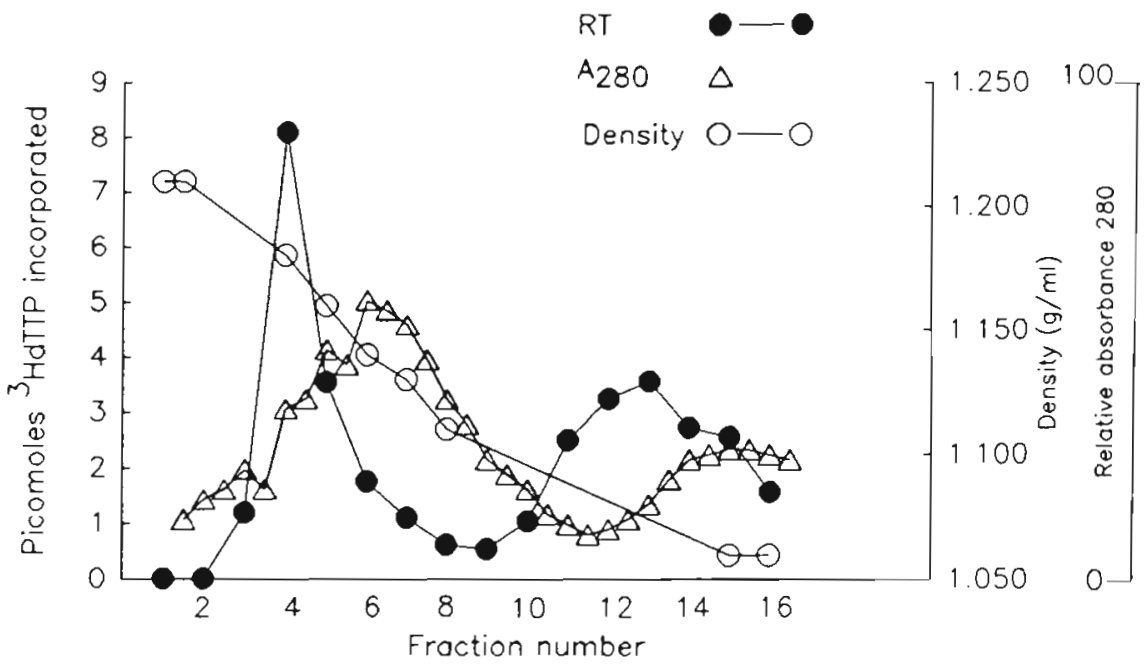

Fig. 1. Sucrose density gradient $(36 \mathrm{ml}, 15 \%$ to $60 \%(\mathrm{w} / \mathrm{v}))$ purification of viral particles from a homogenate of WDS. Strong reverse transcriptase activity is present in fractions with a density of $1.18 \mathrm{~g} \mathrm{ml}^{-1} \mathrm{RT}$ activity is expressed as the amount of incorporated $\left[{ }^{3} \mathrm{H}\right.$ ldTTP 
RT activity using sodium dodecyl sulfate (SDS) (0.5\%) and proteinase $\mathrm{K}\left(100 \mu \mathrm{g} \mathrm{ml}^{-1}\right)$ digestion followed by phenol extraction. The RNA pellet was dissolved in $0.4 \mathrm{ml}$ of diethylpyrocarbonate (DEPC)-treated water and ethanol-precipitated twice. The final pellet was resuspended in $100 \mu \mathrm{l}$ of TE $(10 \mathrm{mM}$ Tris- $\mathrm{HCl}, 1 \mathrm{mM}$ ethylene-diaminetetraacetate (EDTA), $\mathrm{pH}$ 7.8).

cDNA synthesis and labeling. CDNA synthesized from purified RNA was labeled using a nonradioisotopic method based on the incorporation of digoxigenin-labeled deoxyuridine-triphosphate conjugate (Genius ${ }^{T M}$, Boehringer Mannheim Biochemicals, USA). This procedure provides single copy sensitivity as assessed with bovine leukemia virus specific probes and known copy number standards (Renshaw \& Casey unpubl. obs.). Briefly, $0.5 \mu \mathrm{g}$ of viral RNA was mixed with $\mathrm{RT}$ buffer $(50 \mathrm{mM} \mathrm{M}$ Tris- $\mathrm{HCl}, \mathrm{pH} 8.3,40 \mathrm{mM}$ $\mathrm{KCl}, 7 \mathrm{mM} \mathrm{MgCl}, 1 \mathrm{mM} \mathrm{DTT}, 0.1 \mathrm{mg} \mathrm{ml}^{-1}$ bovine serum albumin), $1 \mu \mathrm{g}$ of random calf thymus oligonucleotides primers (average size of 10 nucleotides), 7 units of avian myeloblastosis RT (Promega, USA) and deoxynucleotide triphosphates (dATP, dCTP, and dGTP at $100 \mu \mathrm{M}$, and dig-dUTP at $35 \mu \mathrm{M}$ ) in a total of $20 \mu \mathrm{l}$. The mixture was incubated for $2 \mathrm{~h}$ at $37^{\circ} \mathrm{C}$.

Formaldehyde agarose gel electrophoresis of RNA. RNA $(3 \mu \mathrm{g})$ was electrophoresed on a vertical apparatus in a $1 \%$ agarose gel prepared with DEPC water, Tris-borate $(45 \mathrm{mM}$ Tris-borate, $\mathrm{pH} 8.0,1 \mathrm{mM}$ EDTA) and 2.2 M formaldehyde. Electrophoresis was carried out as described (Sambrook et al. 1989). To confirm that the bands visualized under UV illumination were RNA, the gel was incubated $2 \mathrm{~h}$ at room temperature in $250 \mathrm{ml}$ of $100 \mathrm{mM}$ Tris- $\mathrm{HCl}, \mathrm{pH} 7.5$, containing bovine pancreatic RNase $\left(40 \mu \mathrm{g} \mathrm{ml} \mathrm{ml}^{-1}\right)$ (Sigma, USA). Molecular sizes (kb) of RNA species were calculated using a 0.24 to $9.4 \mathrm{~kb}$ RNA ladder (Bethesda Research Laboratories, Gaithersburg, MD, USA).

DNA isolation. DNA was isolated from hepatic tissue of 5 normal walleye fingerlings $(0.7 \mathrm{~g}$ per fingerling) collected from the South Otselic Fish Hatchery of the New York State Department of Environmental Conservation and from tumor tissue collected from 2 adult walleyes in April 1989. Tissues were homogenized in extraction buffer $(10 \mathrm{mM}$ Tris- $\mathrm{HCl}, \mathrm{pH} 8.0,50 \mathrm{mM}$ EDTA, pH 8.0, proteinase $\mathrm{K}\left(100 \mu \mathrm{g} \mathrm{ml} \mathrm{m}^{-1}\right), 1 \% \mathrm{w} / \mathrm{v}$ SDS). After overnight digestion, the lysate was extracted once with an equal volume of chloroform/ isoamyl alcohol $(24: 1 \mathrm{v} / \mathrm{v})$ and ethanol-precipitated. After treatment with RNase $\left(100 \mu \mathrm{g} \mathrm{ml}^{-1}\right)$, DNA was extracted twice more with chloroform: isoamyl alcohol, ethanol-precipitated and quantified by UV spectrophotometry.

Agarose gel electrophoresis of DNA and Southern blot analysis. DNA (10 $\mu \mathrm{g})$ isolated from WDS and from normal walleye fingerling hepatic tissue was digested with EcoRI restriction enzyme as described by the manufacturer (New England Biolabs, Inc., USA), fractionated on a $0.9 \%$ agarose gel and transferred to a nitrocellulose sheet following the procedure described (Sambrook et al. 1989). The blot was incubated for $12 \mathrm{~h}$ at $65^{\circ} \mathrm{C}$ in $10 \mathrm{ml}$ of prehybridization solution containing $5 \times \mathrm{SSC}(15 \mathrm{mM}$ sodium citrate, $150 \mathrm{mM}$ sodium chloride, $\mathrm{pH} 7.0$ ), $0.5 \%$ blocking reagent (Genius ${ }^{\mathrm{TM}}$, Boehringer-Mannheim), $0.1 \% \quad$ N-lauroyl-sarcosine, $0.02 \%$ SDS and $100 \mu \mathrm{g} \mathrm{ml}^{-1}$ calf thymus RNA (Sigma). Hybridization was carried out at $65^{\circ} \mathrm{C}$ for $60 \mathrm{~h}$ in $10 \mathrm{ml}$ of the above solution containing the labeled denatured cDNA probe $(20 \mu \mathrm{l})$.

\section{RESULTS}

\section{Purification of viral particles}

After 2 successive purifications by equilibrium density gradient centrifugation, a major peak of RT activity was associated with 2 fractions $(4 \mathrm{ml})$ with a density of $1.18 \mathrm{~g} \mathrm{ml}^{-1}$ (Fig. 1). This fractionation scheme was effective at separating cellular debris from virus particles as indicated by the peak of UV light absorbance which was found in fractions of lower density.

\section{Electron microscopy}

In the fractions with highest enzymatic activity, electron microscopic examination (EM) verified that the purification scheme effectively separated viral particles from cell debris. EM revealed the presence of numerous, often clustered, $90 \mathrm{~nm}$ in diameter, viral particles with prominent spikes protruding from the viral envelope (Fig. 2). Negative stain which had penetrated into the particles allowed internal structures to be observed: a round, centrally located, electron-dense nucleoid surrounded by a wide electron-lucent space. An outer thin electron-dense envelope was sometimes present around this space. Some empty collapsed envelopes were also present.

\section{RNA isolated from fractions with $\mathrm{RT}$ activity}

Formaldehyde agarose gel electrophoretic analysis of RNA prepared from sucrose-banded virions is shown in Fig. 3. A discrete RNA band, ca $12 \mathrm{~kb}$ in length, was visualized. In addition, heterogenous RNA species were detected in the $0.25 \mathrm{~kb}$ size range. Both the $12 \mathrm{~kb}$ and $0.25 \mathrm{~kb}$ RNA species were sensitive to pancreatic RNAse treatment. This material was subsequently used 


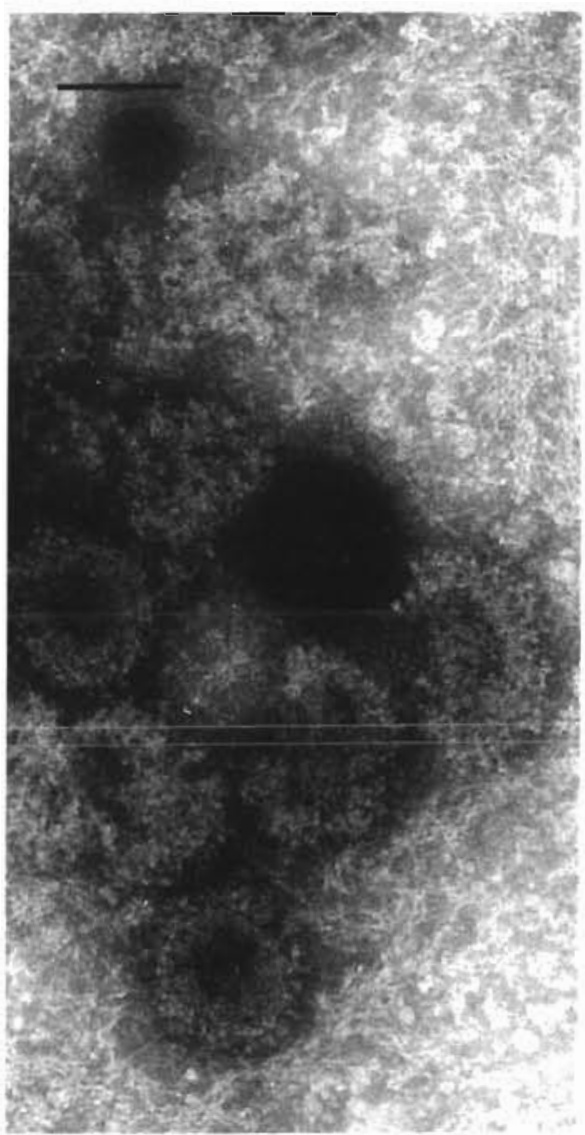

Fig. 2. Pellet from 3 pooled, purified, RT active fractions from sucrose density gradient. Negatively stained viral particles are present. Clusters of viral particles $(100 \mathrm{~nm})$ are present amongst debris, presumably collagen fibrils. Viral particles have a circular and central electron-dense core surrounded by a wide electron-lucent space. Spikes conspicuously protrude from the viral envelope. Stain: phosphotungstic acid. Bar = $100 \mathrm{~nm}$

for synthesis of labeled cDNA and employed as a probe for hybridization with genomic DNA from 2 different walleye dermal sarcomas and from normal walleye fingerlings. The absence of visually detectable $28 \mathrm{~S}$ or $18 \mathrm{~S}$ ribosomal RNA in the preparation suggests that this procedure was effective at eliminating contaminant cellular RNA.

\section{Southern blot analysis}

Hybridization of the digoxigenin-labeled cDNA probe with undigested genomic DNA from 2 different WDS-affected walleyes showed the presence of a homologous, unintegrated $13 \mathrm{~kb}$ DNA species. This DNA species was not detected in genomic DNA of normal walleye fingerling hepatic tissue (Fig. 4a). In additional experiments, there was no hybridization with undigested genomic DNA from a channel catfish ovary cell line nor with DNA from bovine lymphosarcoma (data not shown). Hybridization of the cDNA probe with EcoRI digested genomic DNA from another tumor demonstrated the presence of 2 DNA fragments, 5.9 and $6.1 \mathrm{~kb}$ in size (Fig. $4 \mathrm{~b}$ ). The sum of the 2 fragments closely approximated the anticipated size of a linear full-length viral genome. In contrast, the labeled probe did not detect any homologous DNA species in EcoRI digested DNA from the other aforementioned animal species.

\section{DISCUSSION}

We have previously demonstrated the transmissibility of WDS by inoculation of cell-free tumor homogenates (Martineau et al. 1990a). In spontaneous tumors, we have now detected viral particles having a morphology and a density similar to those of oncornaviruses. In addition, we have demonstrated that a high RT activity is associated with the purified virions. The diameter $(90 \mathrm{~nm})$ and the morphology of these negatively stained retrovirus-like particles are similar to those of retrovirus type $\mathrm{C}$ particles observed in thin

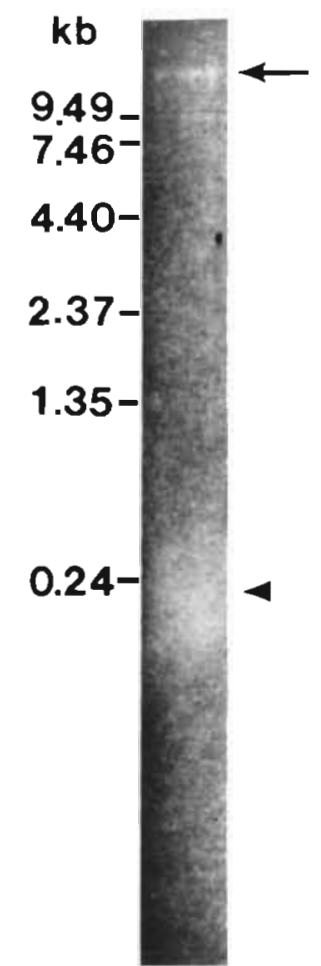

Fig. 3. Formaldehyde agarose gel electrophoretic analysis of total RNA isolated from a RT active fraction. A discrete RNA species, ca $12 \mathrm{~kb}$ in size, is present (arrow). Smaller heterogeneous RNA species are present in the $0.25 \mathrm{~kb}$ size range (arrowhead). Total RNA was isolated from a fraction with high RT activity. Molecular sizes at left in kilobases ( $\mathrm{kb}$ ) are represented by a 0.24 to $9.4 \mathrm{~kb}$ RNA ladder 
sections of tumors transmitted in walleye fingerlings by inoculation of cell-free tumor homogenate (Martineau et
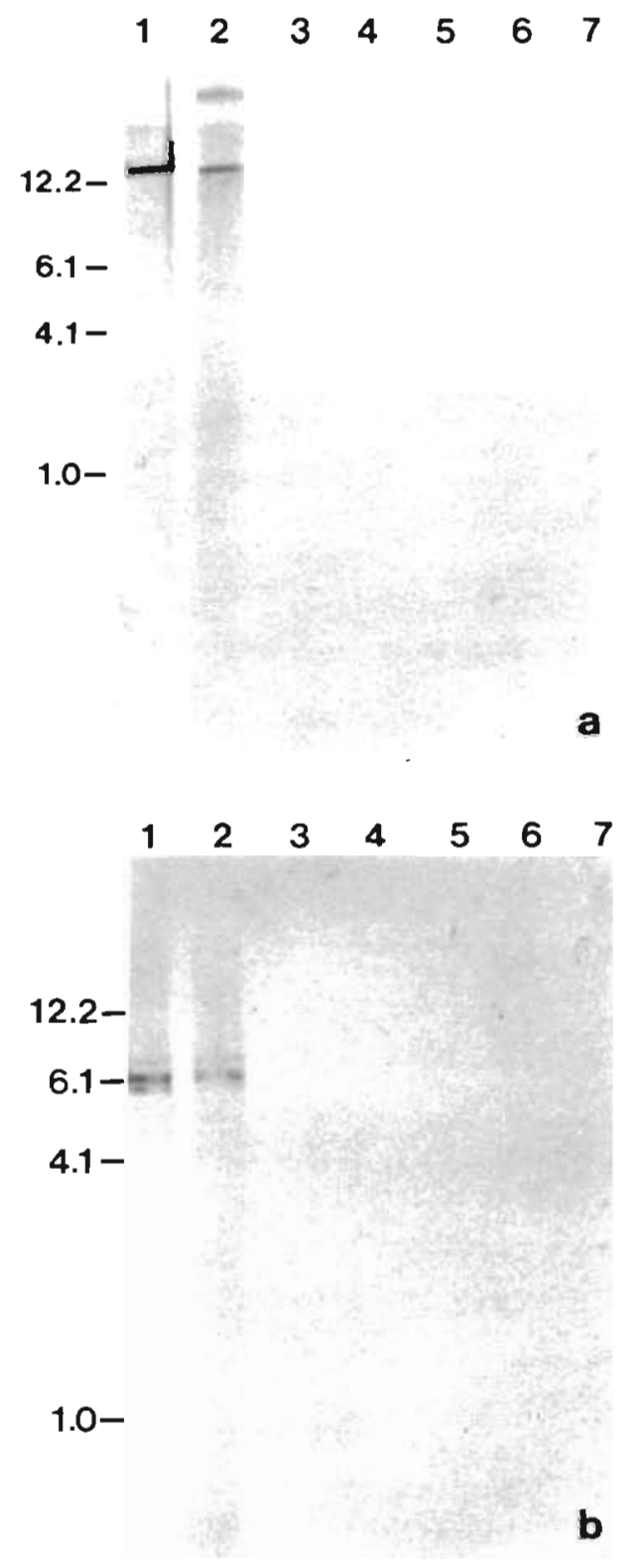

Fig. 4. (a) Southern analysis of undigested DNA from WDS from 2 different fish (lanes 1 and 2) and from 5 nomal walleye fingerling livers (lanes 3 to 7 ). The probe was digoxigeninlabeled CDNA synthesized from viral RNA isolated from RT active fractions. This probe detects the presence of a homologous, unintegrated $13 \mathrm{~kb}$ DNA species in tumor tissue only (lanes 1 and 2). Molecular size markers at left in kilobases ( $\mathrm{kb}$ ) correspond to 1 to 12 repeats of a $1.018 \mathrm{~kb}$ DNA fragment. (b) Southern analysis of EcoRI digested DNA from WDS from 2 different fish (lanes 1 and 2) and from 5 normal fingerling livers (lanes 3 to 7 ). The probe was digoxigenin-labeled cDNA synthesized from viral RNA isolated from RT active fractions. The probe detects the presence of 2 DNA fragments (5.9 and $6.1 \mathrm{~kb}$ ) (lanes 1 and 2). Molecular size markers at left in kilobases (kb) correspond to 1 to 12 repeats of a $1.018 \mathrm{~kb}$ DNA fragment al. 1990a). Differences in the preparation techniques may account for the $10 \mathrm{~nm}$ smaller size of the viruses described here (Fig. 2). Morphologically, the particles that we observed differ somewhat from prototypic type C particles in that they have finer spikes and a smaller core.

An unexpected finding relates to the number of viruses present in tumors and to the integrity of viral RNA. At least $10 \%$ of the total RNA recovered represented undegraded genome length molecule (Fig. 3). Since the total amount of viral RNA present in the 2 most RT active fractions is ca $40 \mu \mathrm{g}$ and assuming that the viral genome is $12 \mathrm{~kb}$ in length ( $24 \mathrm{~kb}$ diploid), we conservatively calculate from the estimated amount of full length viral RNA $(4 \mu \mathrm{g})$ that $17 \times 10^{10}$ viral particles were present in $14 \mathrm{~g}$ of tumor. Since $1 \mathrm{~g}$ of tumor contains ca $10^{9}$ tumor cells (Tannock 1983), WDS contains a minimum average of 12 viruses per tumor cell. Further, the large amount of intact viral RNA present in thawed tumors submitted to a relatively extensive purification procedure suggests that WDSV may not be as labile as mammalian retroviruses. This unusual viral stability, possibly required for virus transmission in nature, needs to be further investigated.

The specificity of the labeled cDNA probe synthesized from viral RNA was demonstrated by its hybridization with a $13 \mathrm{~kb}$ unintegrated DNA species found only in dermal sarcoma. This DNA species was not detected in tissue from normal walleye fingerlings (Fig. $4 \mathrm{a}, \mathrm{b})$. The fragments resulting from EcoRI digestion of genomic tumor DNA add to ca $13 \mathrm{~kb}$. Considered together, these findings suggest that the $13 \mathrm{~kb}$ DNA detected in tumors represent the unintegrated linear form of WDSV DNA. The present study generated the information and the reagents that will be necessary to molecularly clone the WDSV. In turn, the availability of WDSV molecular clones will allow us to more fully characterize the retroviral etiology of WDS.

Acknowledgements. We thank Dr Olafur Andersson and Carol Kim for useful discussion and editorial assistance. The help provided by Ms M.J Zanelli and Mr E.P. Dougherty of the Department of Pathology for use of the electron microscope facility and by Mr J. Telford for photographs is acknowledged. This work was supported in part by funds from the United States Department of Agriculture Animal Health and Disease Program administered through the New York State College of Veterinary Medicine. D.M. is funded through a post-doctoral fellowship from the Medical Research Council of Canada.

\section{LITERATURE CITED}

Bowser, P. R., Wolfe, M. J., Forney, J. L., Wooster, G. A. (1988). Seasonal prevalence of skin tumors from walleye (Stizostedion vitreum) from Oneida lake, New York. J. Wildl. Dis. 24: 292-298

Bowser, P. R., Martineau, D., Wooster, G. A. (1990). Effects of water temperature on experimental transmission of dermal 
sarcoma in fingerling walleyes Stizostedion vitreum. J. aquat. Anim. Health 2: 157-161

Brown, E. R., Dolowy, W. C., Sinclair, T., Keith, L., Greenberg, S., Hazdra, J. J., Beamer, P., Callaghan, O. (1976). Enhancement of lymphosarcoma transmission in Esox lucius and its epidemiologic relationship to pollution. In: Clemmesen, J., Yohn, D. S., (eds.) Comparative leukemia research. Karger, Basel, p. 245-251

Duncan, I. B. (1978). Evidence for an oncovirus in swimbladder fibrosarcoma of Atlantic Salmon Salmo salar L. J. Fish Dis. 1: $127-131$

Martineau, D., Bowser, P. R., Wooster, G. A., Armstrong, L. D. (1990a). Experimental transmission of a dermal sarcoma in fingerling walleyes (Stizostedion vitreum vitreum). Vet. Pathol. 27: 230-234

Martineau, D., Bowser, P. R., Wooster, G. A., Forney, J. I. (1990b). Dermal sarcoma of walleye (Pisces: Stizostedion vitreum). Histological and ultrastructure studies. Vet. Pathol. 27: 340-346

Masahito, P., Ishikawa, T., Sugano, H. (1988). Fish tumors and their importance in cancer research. Jpn. J. Cancer Res. (Gann) 79: 545-555

Mulcahy, M. F., O'Leary, A. (1970). Cell-free transmission of lymphosarcoma in the northern pike Esox lucius (Esocidae). Experientia 26: 891

Responsible Subject Editor: W. Ahne, Munich, Germany
Papas, T. S., Dahiberg, J. E., Sonstegard, R. A. (1976). Type C virus in lymphosarcoma in northern pike (Esox lucius). Nature, Lond. 261: 506-508

Sambrook, J., Fritsch, E. F., Maniatis, T (1989). Molecular cloning: a laboratory manual, 2nd edn. Cold Spring Harbor Laboratory Press, Cold Spring Harbor, New York

Sonstegard, R. A. (1976). Studies of the etiology and epizootiology of lymphosarcoma in northern pike (Esox lucius) and muskellunge (Esox masquinongy). In: Clemmesen, J., Yohn, D. S. (eds.) Comparative leukemia research. Karger, Basel, p. 242-244

Tannock, I. F. (1983). Biology of tumor growth. Hosp. Pract. 18 (4): $81-93$

Walker, R. (1969). Virus associated with epidermal hyperplasia in fish. Natl. Cancer Inst. Monogr. 31: 195-207

Yamamoto, T., MacDonald, R. D., Gillespie, D. C., Kelly, R. K. (1976). Viruses associated with lymphocystis disease and dermal sarcoma of walleye (Stizostedion vitreum vitreum). J. Fish. Res. Bd Can. 33: 2408-2419

Yamamoto, T., Kelly, R. K., Nielsen, O. (1983). Epidermal hyperplasias of northern pike Esox lucius associated with Herpesvirus and C-type particles. Arch. Virol. 79: 255-272

Yamamoto, T., Kelly, R. K., Nielsen, O. (1985), Morphological differentiation of virus-associated skin tumors of walleye (Stizostedion vitreum vitreum). Fish Pathol. 20: 361-372

Manuscript first received: October 31, 1990 Revised version accepted: February 7, 1991 